\title{
PRZEKEADY
}

\author{
Horst BREDEKAMP
}

\section{OD ZAMKU BERLIŃSKIEGO DO FORUM HUMBOLDTÓW: PARADYGMAT KONFLIKTU W NIEMIECKIEJ HISTORII}

\section{Szanowni Państwo,}

możliwość wystąpienia w ramach obchodów 100-lecia Instytutu Historii Sztuki w Poznaniu stanowi dla mnie wielki zaszczyt. Założyciel Instytutu, Szczęsny Dettloff, należy do znamienitych przedstawicieli historii sztuki ostatniego stulecia. Orientując się szczególnie na włoski renesans i regionalną historię sztuki jako bezpośrednie fundamenty swych badań, stał się wybitną postacią w niemieckojęzycznej historii sztuki jako specjalista w zakresie średniowiecza i północnego renesansu, szczególnie w odniesieniu do Wita Stwosza. Studiował również u Heinricha Wölfflina, prawdopodobnie jeszcze w jego berlińskich latach. W nieszczęsnym okresie, kiedy w miejsce Uniwersytetu w Poznaniu w roku 1941 powstał niemiecki Uniwersytet Rzeszy, jedynym pojednawczym momentem był fakt zwolnienia Dettloffa z obozu dla internowanych w roku 1939 dzięki interwencji Karla-Heinza Clasena. Z racji swych związków ze szkołą wiedeńską, zwłaszcza z Maxem Dvořákiem, Dettloff postrzegał zagadnienia badawcze przez pryzmat historii idei i takie podejście przetrwało w poznańskim Instytucie do dziś. Z perspektywy czasu na szczególną uwagę zasługują próby refleksji poznańskiego Instytutu nad współczesną filozofią francuską, a także nad ruchem reformatorskim w zachodnioniemieckiej historii sztuki. Zaproszenie mojego akademickiego nauczyciela Martina Warnke do poznańskiego Instytutu w roku 1973, w okresie zimnej wojny, było ważnym wydarzeniem w historii nauki. W owym czasie nawiązałem luźną znajomość z Adamem Labudą. Później szczęśliwy zbieg okoliczności sprawił, że w roku 1991 obaj zostaliśmy powołani do Wissenschaftskolleg w Berlinie - i stworzyliśmy tam zgraną drużynę tenisa stołowego. To połączyło nas i łączy nas do dziś.

Adam Labuda w jednym ze swoich artykułów na temat historii nauki z ubolewaniem wskazał na to, że niektóre talenty historii sztuki skierowały swą uwagę przede wszystkim na południe i zachód Europy, co dotyczyło rów- 
nież i mnie. Mogę jednak powiedzieć, że kiedy w roku 1993 zostałem mianowany dyrektorem Instytutu Historii Sztuki na Uniwersytecie Humboldtów, zrobiłem wszystko, co było w mojej mocy, aby wbrew znacznym sprzeciwom zachować Katedrę Historii Sztuki Europy Wschodniej. Było szczęśliwą okolicznością, że udało się nam wówczas pozyskać Adama Labudę na profesurę związaną z tą katedrą. Dzięki temu nawiązane zostały bliskie kontakty z Poznaniem, wzmacniane również przez innych kolegów, zwłaszcza przedwcześnie zmarłego Piotra Piotrowskiego, który przez kilka semestrów wykładał na Uniwersytecie Humboldta, ujmując zarówno kolegów, jak i studentów swym otwartym sposobem bycia. W ramach ugruntowanych kontaktów między Poznaniem a instytutem berlińskim Piotr Korduba poprosił mnie o odczyt na
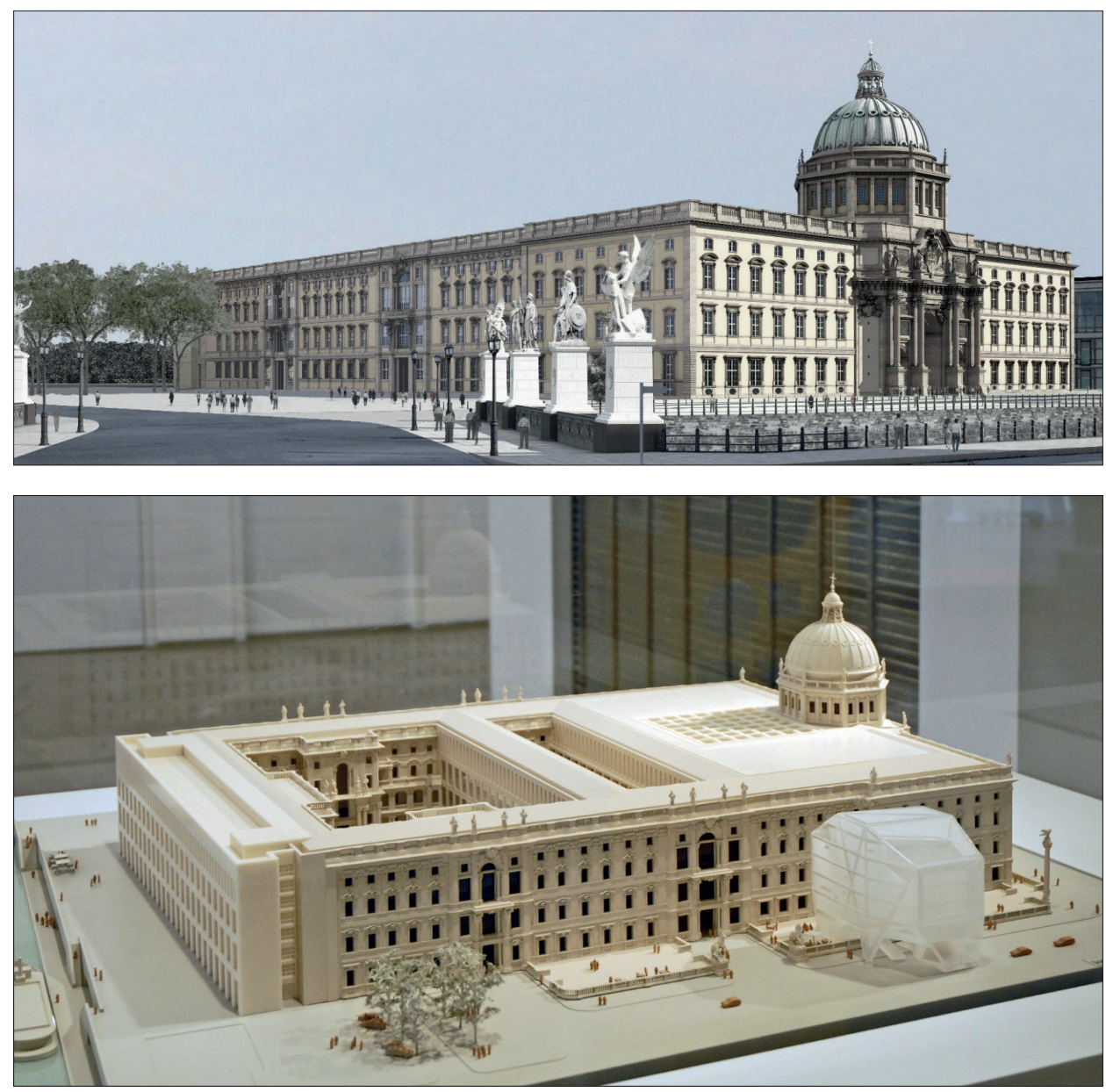

1 A-B. Frank Stella, modele Zamku Berlińskiego/Forum Humboldtów 
dzisiejszych obchodach jubileuszowych. Wyraził życzenie, abym wypowiedział się na temat Zamku Berlińskiego oraz Forum Humboldtów, nad którego powstaniem pracowałem przez trzy lata jako jeden z członków komitetu założycielskiego.

Jeszcze przed otwarciem Forum Humboldtów wywołało dyskusję wykraczającą daleko poza granice Berlina, a także Republiki Federalnej Niemiec i Europy (il. 1 A-B). Projekt ten postrzegany jest zarówno w dobrym, jak i negatywnym świetle jako przypadek szczególny, w którym łączą się ogólne oceny historii z pytaniami o kształtowanie przyszłości. Nie wiadomo jeszcze, czy okaże się on modelem, czy też postrzegany będzie jako wypadek w historii, i pytanie to być może oceniane będzie inaczej z Państwa perspektywy historycznej aniżeli z mojej. Mam jednak nadzieję, że zdołam nabrać odpowiedniego dystansu, aby przedstawić Państwu problematykę, która zapewne nie dotyczy jedynie samego Berlina. Chciałbym przybliżyć tę tematykę w dziesięciu krokach. Pierwszym będzie spojrzenie z perspektywy rzymskiej.

\section{PERSPEKTYWA RZYMSKA}

Swą mieszanką stylów późnego gotyku i renesansu Zamek Berliński około roku 1670 nie mógł wywołać większego wrażenia na skalę ponadregionalną. Jego właściciele, Hohenzollernowie, byli władcami elektoratu brandenbursko-pruskiego, który wprawdzie miał pewne znaczenie, nie równał się jednak $z$ królestwami europejskimi. Kierowany ambicją nadania Prusom godności królewskiej elektor Fryderyk III dokonał aktu samokoronacji na obrzeżach państwa pruskiego - w Królewcu, w celu złagodzenia wrażenia samowoli tego kroku w oczach potentatów europejskich. Wobec opisanego deficytu legitymacji jego władzy królewskiej, Fryderyk - wówczas już jako król Fryderyk I - dokładał wszelkich starań, aby poprzez swój odnowiony zamek miejski dorównać poziomowi aspiracji mocarstw europejskich. Nawiązał do Rzymu, aby skorzystać z politycznej ikonologii caput mundi. Jego osobiste zainteresowanie Rzymem nie było w żadnym wypadku pozorowane; wręcz przeciwnie - należał on do grona uczonych, którzy ze znacznym zaangażowaniem osobistym i wkładem finansowym starali się odkrywać świat antyku. Przeznaczył znaczne fundusze na zakup monet i medali antycznych oraz publikacji na ten temat.

Protagonistą przekształcenia późnogotyckiego zamku w barokowy pałac stał się Andreas Schlüter, prawdopodobnie urodzony w Gdańsku około roku 1660 (il. 2). O jego wykształceniu i początkowym okresie twórczości w miejscu urodzenia wnioskować można jedynie na podstawie przypisywanych 


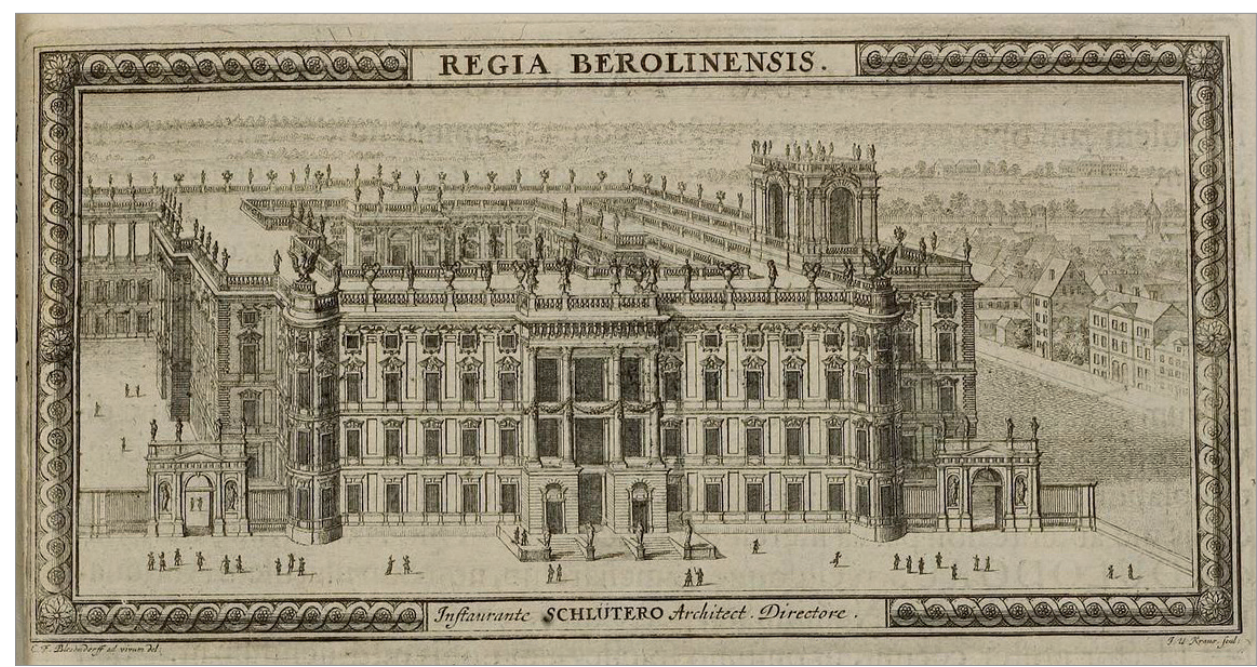

2. Zamek Berliński, miedzioryt, 1696-1701

mu rzeźb. Należą do nich sztukaterie przedstawiające kontynenty w domu przy Długim Targu 7/8 (zniszczone), które ukazują żartobliwą próbę oswojenia lwa przez putta. Przypisywane mu są także figury puttów w pałacu króla Jana III Sobieskiego w Wilanowie, symbolizujące cztery żywioły, między innymi wodę. Udokumentowany źródłowo jest udział Schlütera w roku 1689 w wykonaniu wystroju warszawskiego pałacu Krasińskich, z charakterystycznymi scenami z okresu republiki rzymskiej. Pewne jest jego autorstwo nagrobków ojca i wuja króla Jana Sobieskiego w farze w Żółkwi z lat 1692-1694, wykonanych z czarnego marmuru, oraz figur asystujących, stanowiących prawdopodobnie personifikacje Siły, Sprawiedliwości oraz Cnoty i Prawdy, a także postaci Famy nad urnami. Nagrobki te zadecydowały, zapewne wraz $z$ innymi dziełami rzeźbiarza, o powołaniu go w roku 1694 na stanowisko dyrektora budowy zamku w Berlinie. Przy wszystkim, co teraz zostanie powiedziane, należy pamiętać, że to polski artysta dworski w osobie Andreasa Schlütera wzniósł Zamek Berliński.

Zanim Schlüter rozpoczął pracę nad opracowaniem projektu, spędził kilka miesięcy we Włoszech, między innymi w Rzymie, aby zyskać szerszą perspektywę, niezbędną do uwolnienia Berlina od wpływów lokalnej tradycji architektonicznej. Bezpośrednim wzorem dla projektu berlińskiego zamku stał się rzymski Palazzo Madama Paolo Marucelliego, położony niedaleko Piazza Navona (il. 3, 4). Odnosi się wrażenie, jakby Schlüter w Berlinie po prostu rozbudował ten obejmujący trzy i pół piętra pałac. Nawet formy okien są identyczne, wyjąwszy różnicę formy łuków od- 


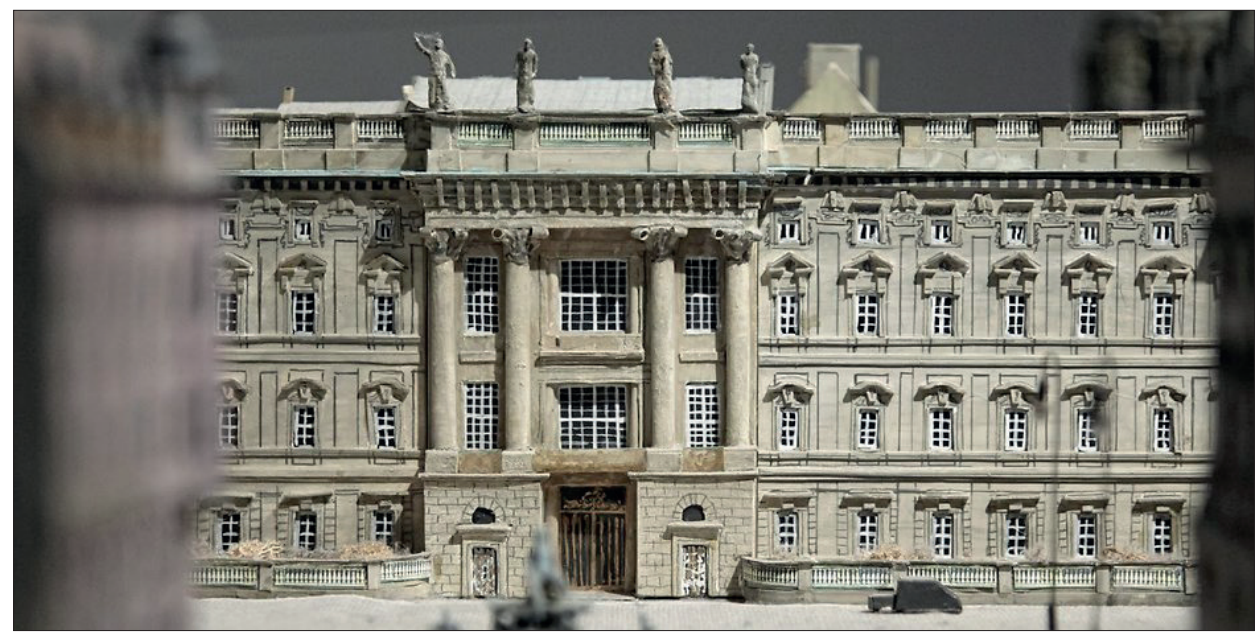

3. Zamek Berliński, fragment elewacji

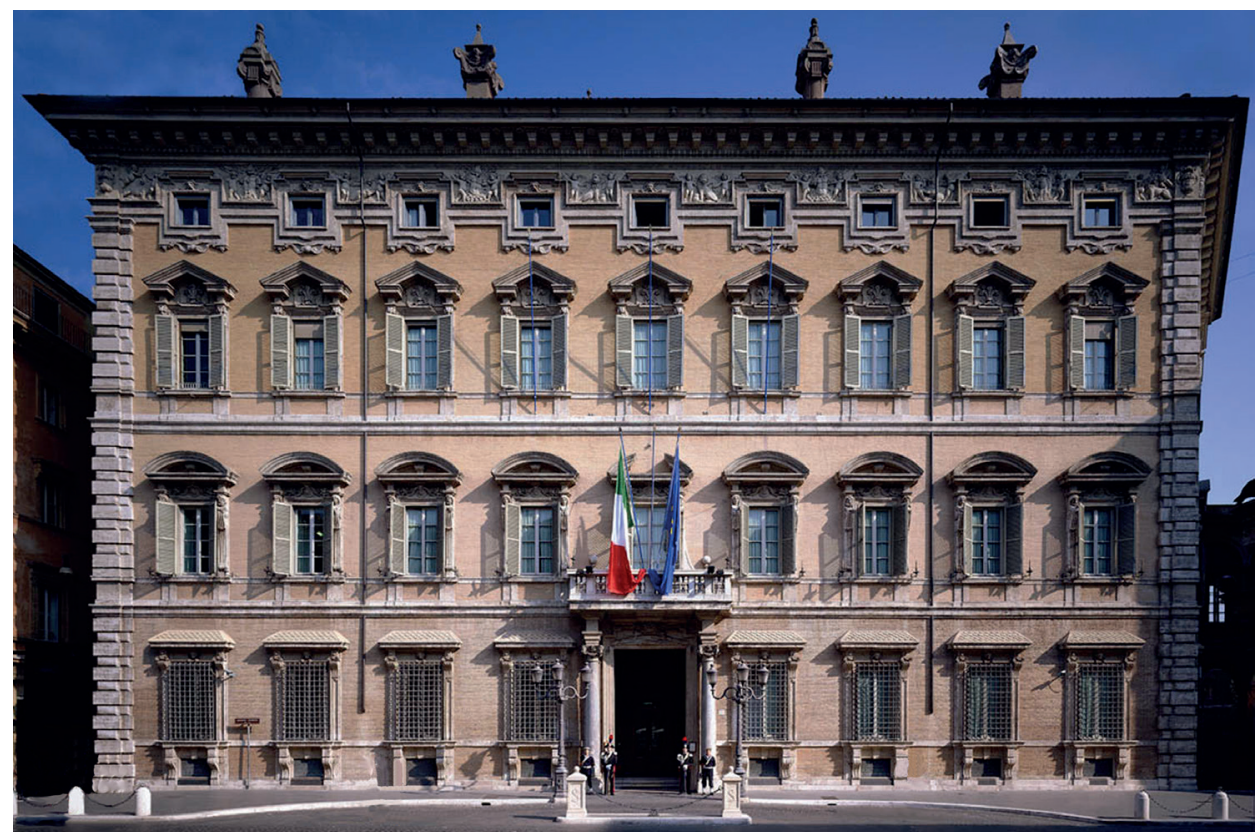

4. Paolo Marucelli, Palazzo Madama, Rzym, 1637-1642

cinkowych na pierwszym piętrze. Przejęto również niezwykłe przeprucie gzymsu oknami mezzanina, wprowadzające plastyczny element do surowej szaty architektonicznej elewacji. Jedyną różnicę stanowi fakt, że w Berlinie w polach figuralnych umieszczonych między oknami nad gzymsem, 
w miejsce występujących w Palazzo Madama bawiących się puttów, przedstawiono orły, odnoszące się zarówno do Jowisza, jak i do Prus. Potężne kolumny Wielkiej Klatki Schodowej dźwigają nad impostami i potężnym gzymsem jedynie figury górnej kondygnacji. Zainspirowane są z pewnością kolumnami z dziedzińców perystylowych na forum Nerwy. W ryzalicie Wielkiej Klatki Schodowej te antyczne rzymskie elementy przejmują funkcję autonomicznego przedstawienia samych siebie: stają się symbolami swej własnej formy.

Dokonana w roku 1708 przez następcę Schlütera, Johanna Friedricha Eosandera, rozbudowa gmachu zamkowego w kierunku zachodnim zadecydowała o ostatecznym wyglądzie Zamku Berlińskiego (il. 5). W zapewne najbardziej charakterystycznym motywie tej partii zamku - portalu III w ele-

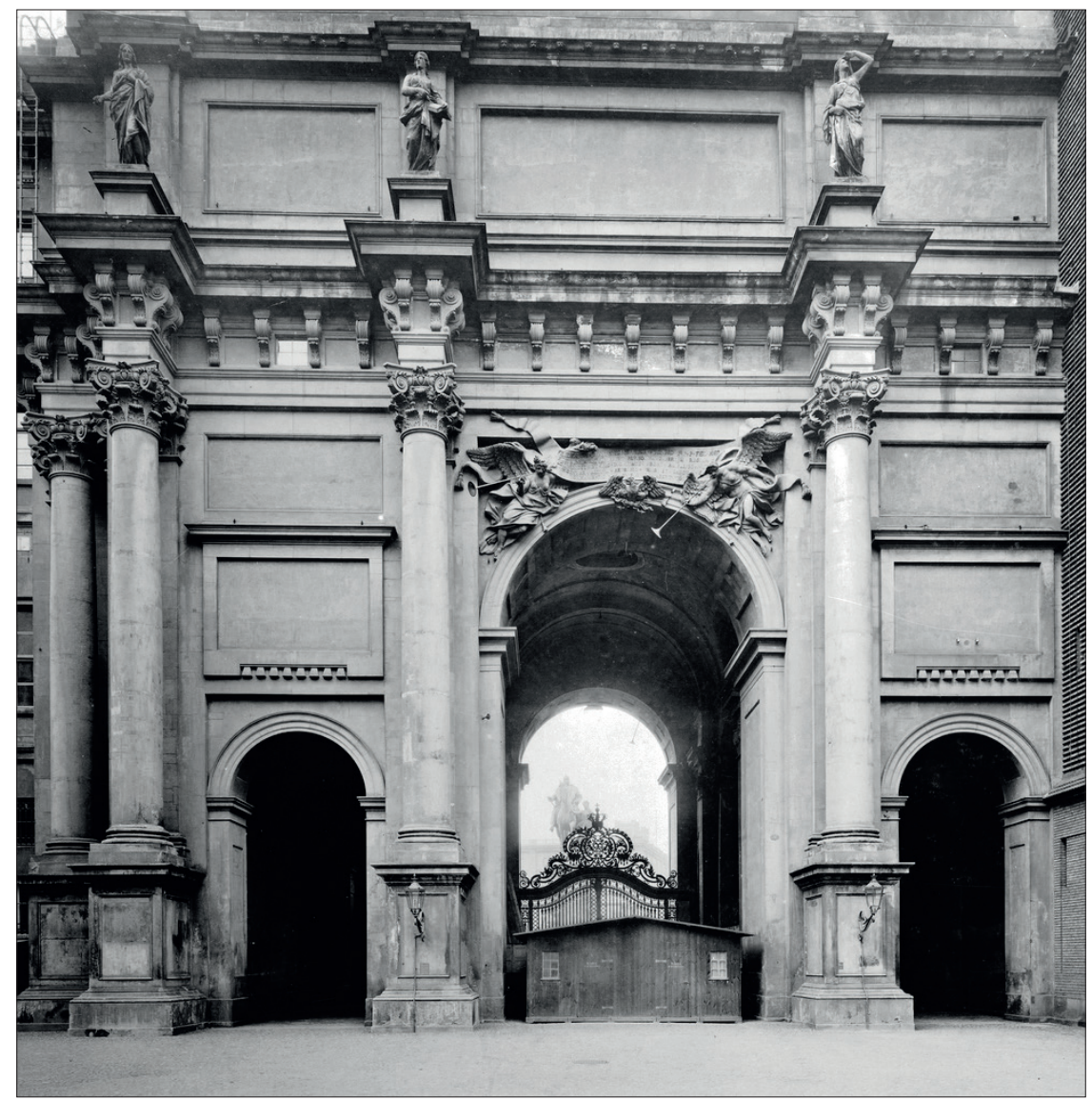

5. Johann Friedrich Eosander, Zamek Berliński, fasada dziedzińcowa, portal III, $1708-1716$ 
wacji zachodniej - ponownie przytoczono formy rzymskiego antyku. Elewacje zewnętrzne i dziedzińcowe - cytując raz Łuk Konstantyna, a innym razem wybudowany w roku 203 Łuk Septymiusza Sewera - nawiązują do dwóch łuków tryumfalnych z Forum Romanum (il. 6). Porównanie wewnętrznego portalu Eosandera $z$ Łukiem Septymiusza Sewera z rzymskiego Forum Romanum ukazuje, jak wiernie Rzym został w tym miejscu przeniesiony do Berlina. Wrażenie jest imponujące, choć jednowymiarowo cezariańskie. Formy Schlütera stanowiły natomiast swoistą summę architektonicznej i artystycznej historii Rzymu od starożytności przez renesans do współczesnego artyście baroku. Nie łączą zaczerpniętych elementów w sposób kompilacyjny, lecz dramatyzują je, aby mocniej podkreślić dynamikę podziałów architektonicznych i rozwinąć własny styl plastyczny: śródziemnomorski teatr plastyczności, wewnętrznego napięcia i żywotności.

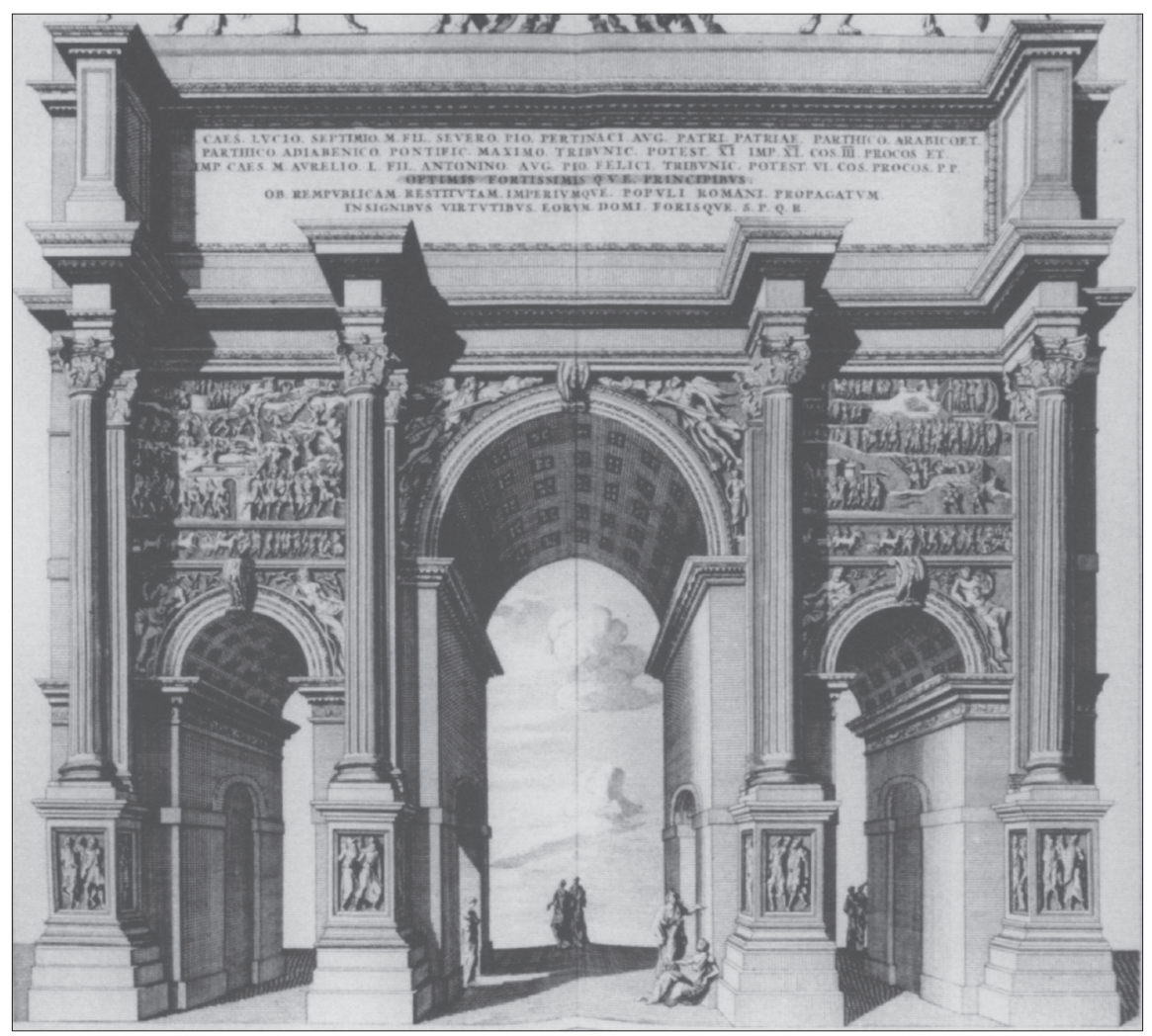

6. Łuk Septymiusza Sewera, Rzym, 203 n.e., akwaforta, 1694-1699 


\section{GABINET OSOBLIWOŚCI (KUNSTKAMMER) JAKO MUZEUM AKADEMICKIE}

Pomimo rygorystycznych przekształceń szaty zewnętrznej zamek we wnętrzu niezmiennie pozostawał związany ze swą pierwotną funkcją, służąc jako rezydencja królewska, ale pełniąc również funkcje publiczne jako siedziba sądów, urzędów skarbowych, banków, sklepów, biblioteki oraz gabinetu osobliwości, dostępnego przynajmniej dla specjalistów i zainteresowanych laików. Zbiory gabinetu, gromadzone przez pokolenia, uległy wprawdzie rozproszeniu podczas wojny trzydziestoletniej, lecz zostały odbudowane tak skutecznie, że stały się jednym z impulsów dla Gottfrieda Wilhelma Leibniza, aby postrzegać berlińską Akademię Nauk, którą pomógł założyć w roku 1700, jako „Teatr natury i sztuki”. Gabinet osobliwości miał być dostępny badaczom. Jako muzeum powszechne obejmował zarówno eksponaty przyrodnicze, jak i instrumenty badawcze, wreszcie także dzieła sztuki. Opieka nad tą kolekcją oscylowała między troskliwym nadzorem a zaniedbaniem, choć szeroki zakres jej zasobów sto lat później, około roku 1800, uczynił ją szczególnie interesującą. W tym bowiem czasie gabinet osobliwości został podporządkowany Akademii Nauk i był odtąd mocno wspierany przez Aleksandra i Wilhelma von Humboldtów. Stanowiło to wyjątkowy przypadek w historii muzealnictwa, kiedy w czasach, gdy w całej Europie tworzono kolekcje specjalistyczne, umieszczane w galeriach i muzeach sztuki, w muzeach technicznych, a także muzeach historii naturalnej, Berlin w dalszym ciągu trwał przy idei mikrokosmosu całego świata reprezentowanego przez kunstkamerę. Z faktu tego korzyści czerpał przede wszystkim uniwersytet. W roku 1809 Wilhelm von Humboldt sprawił, że powoływany do życia Uniwersytet Berliński, który przynajmniej duchowo miał pomóc społeczności podnieść się z upadku, został wyposażony w zbiory z zakresu nauk przyrodniczych i medycyny, mieszczące się podówczas w kunstkamerze w Zamku Berlińskim (il. 7). Stało się to w roku 1810, kiedy uniwersytetowi przekazany został rozległy pałac brata Fryderyka Wielkiego przy alei Unter den Linden. Zbiory, które znalazły się w tym potężnym budynku, wypełniły go niemal w całości. Kiedy zatem król odwiedził uniwersytet w roku 1820, wpisał do księgi honorowej: „Wspaniałe nowe muzeum!”

W ten sposób uniwersytet stał się dzieckiem Zamku Berlińskiego. Trwająca do roku 1933 historia sukcesu Uniwersytetu Berlińskiego wywodzona jest z propagowanej przez Wilhelma von Humboldta wolności badań i nauczania. Drugi powód ulega jednak najczęściej zapomnieniu: jako spadkobierca znacznej partii zbiorów zamkowych stanowił od początku muzeum powiązane $z$ zadaniami dydaktycznymi. Inne uniwersytety posiadały muzea 


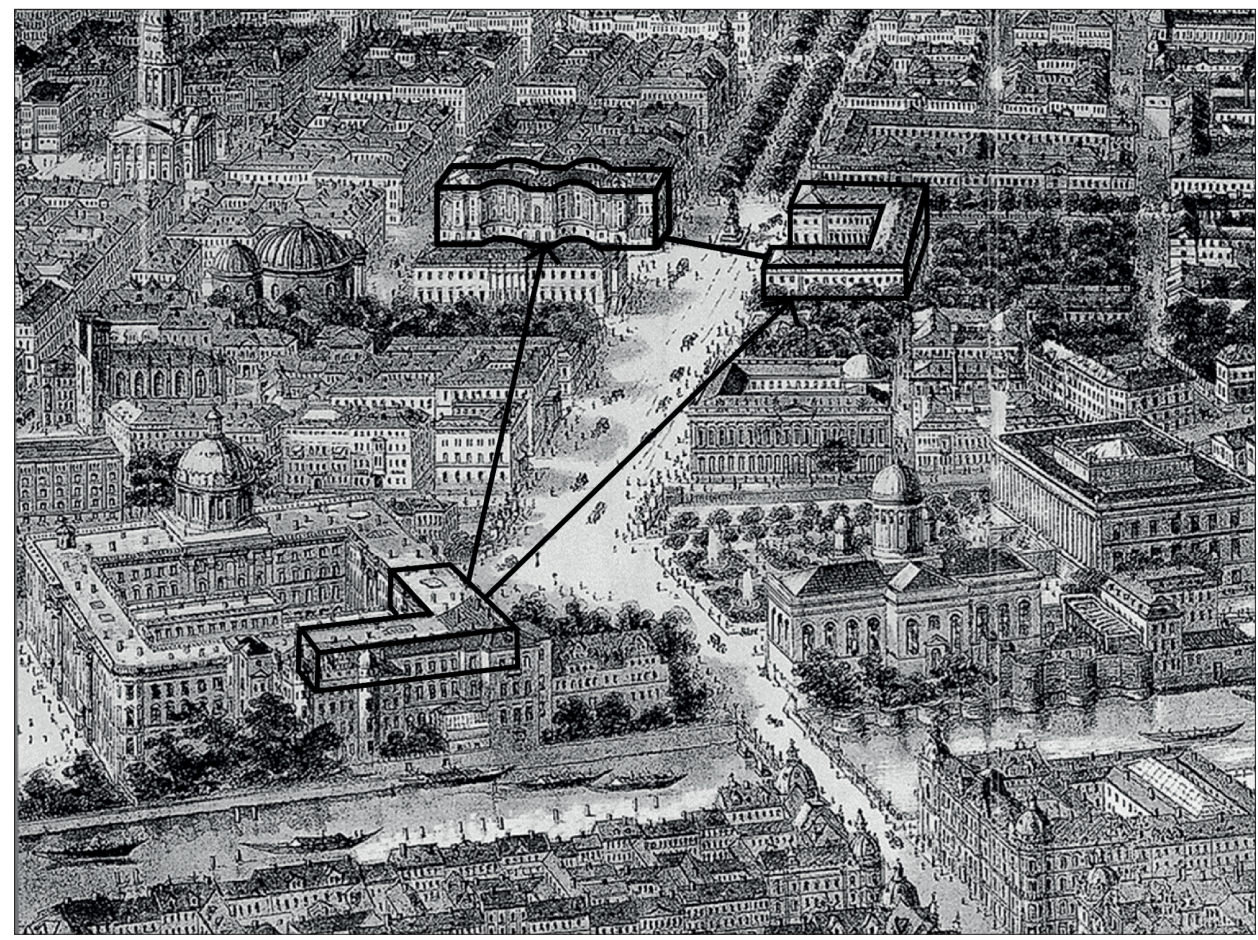

7. Adolf Eltzner, Panorama stolicy Cesarstwa Niemieckiego, 1886

uniwersyteckie, uniwersytet w Berlinie był natomiast żywym muzeum. Fakt ten do dnia dzisiejszego nadaje mu wyjątkowy charakter. Tak więc drugim wartym odnotowania elementem historii zamku jest to, że poprzez zasoby kunstkamery jako akademickiego muzeum powszechnego stał się swego rodzaju „matką” berlińskiej Alma Mater.

\section{HISTORIA SZTUKI POWSZECHNEJ}

Nie mniej ważne aniżeli kolekcje $z$ dziedzin nauk przyrodniczych i medycyny, które przeniesiono z zamkowego gabinetu osobliwości do uniwersytetu, były zgromadzone tam zbiory pozaeuropejskie. Obejmowały one obiekty ze słynnej kolekcji Forsterów. Reinhold Forster i jego syn Georg, którzy towarzyszyli Jamesowi Cookowi w jego drugiej wyprawie dookoła świata, przywieźli ze sobą obszerną kolekcję tysięcy naturaliów i artefaktów, które po swym powrocie w roku 1775 rozdali bądź sprzedali. Nie dziwi fakt dużego zainteresowania tymi obiektami w Berlinie, gdyż Georg Forster niemiecką wersję swojego dziennika podróży, który przyniósł mu sławę na całym świecie, opu- 
blikował właśnie w Berlinie w roku 1778. Z drugiej jednak strony jego nazwisko zostało w Prusach zdyskredytowane, kiedy jako gorący zwolennik rewolucji francuskiej wyemigrował do Paryża.

Po zajęciu Berlina przez wojska francuskie w roku 1806 oprócz najważniejszych dzieł sztuki również znaczna część kunstkamery została zarekwirowana przez Dominique-Vivanta Denona jako łup wojenny i wywieziona do Paryża. Wśród skonfiskowanych i wywiezionych dzieł znalazła się cała kolekcja eksponatów pozaeuropejskich. Pozostały one w całości w Paryżu, gdzie ślad po nich zaginął. Tym bardziej intensywne starania o odbudowę kolekcji etnologicznej podjęli kuratorzy Jean Henry i Leopold baron von Ledebur w kolejnych dziesięcioleciach. Wzrost liczby eksponatów spowodował, że konieczne stało się wprowadzenie systemu inwentaryzacji o strukturze geograficznej, bazującego na podziale na obszary Chin, Japonii, innych regionów Azji, obszary Afryki, Ameryki Północnej, Ameryki Południowej i Australii wraz z regionem południowego Pacyfiku, zasadniczo obowiązującego do dziś. Wprowadzony wówczas podział regionalny, z dzisiejszej perspektywy sprawiający wrażenie raczej mało ciekawej kategoryzacji, w czasach jego ustanowienia był świadectwem dostrzeżenia różnorodności świata. Podobnie jak w teorii językowej Wilhelma von Humboldta, społeczności ludzkie miały być postrzegane nie wertykalnie, w uzależnieniu od stopnia ich ówczesnego rozwoju, lecz horyzontalnie - zgodnie z ich regionalną, autonomicznie pojmowaną kulturą. Dopiero na tej podstawie można było zdefiniować to, co wspólne.

Szczególną rolę zachowały dzieła z kolekcji, która została zgromadzona przez ojca Reinholda i syna Georga Forsterów podczas drugiej podróży Jamesa Cooka dookoła świata. W inwentarzu kunstkamery cały szereg wpisów opatrzono nazwiskiem Forster. Zarząd gabinetu osobliwości dokładał wszelkich starań, by zdobyć przedmioty codziennego użytku z tych zbiorów i odpowiednio je wyeksponować, jak np. maczugi z Tahiti. Pochodzący z roku 1838 rzut poziomy zamkowego gabinetu osobliwości autorstwa Karla Friedricha Schinkla ukazuje zwrócone na południe rozległe sale „zbiorów etnograficznych", dające wyobrażenie o ilości zgromadzonych w nich eksponatów. Zainspirowany wspomnianą kolekcją etnograficzną na zamku, Franz Kugler napisał pierwszą prawdziwą historię sztuki powszechnej, będącą wyrazem owego liberalnego ducha, z którego powstała historia sztuki wszystkich epok i narodów, obejmująca zbiory od kamiennych artefaktów prehistorycznych do współczesności. Stanowi ona pierwsze uniwersalne opracowanie historii homo faber. W swej napisanej pod kątem gabinetu osobliwości berlińskiego zamku syntezie historii sztuki powszechnej Kugler unika wyniesienia teraźniejszości do rangi instancji, która w doskonały spo- 
sób zamykałaby bieg historii i mogła być zdolna do podjęcia refleksji nad nią. W swym relatywistycznym założeniu dzieło to pozostaje wzorcem aż do naszych czasów.

Trzecim elementem o znaczeniu historycznym jest więc fakt, że zbiory etnologiczne gabinetu osobliwości w zamku oferowały materiał poglądowy, który umożliwił wykoncypowanie i napisanie pierwszej liberalnej historii sztuki całego świata, począwszy od artefaktów z epoki kamienia łupanego, i traktującej równorzędnie obszary od Azji do Ameryki.

\section{WYSPA MUZEÓW JAKO „SANKTUARIUM” I TRAUMA ROKU 1848}

Ówczesny gospodarz zamku, Fryderyk Wilhelm IV, jako historyk sztuki-amator, rysownik i zaangażowany mecenas sztuki i nauki, stworzył plan utworzenia na Wyspie Muzeów „sanktuarium sztuki i nauki”, które łączyłoby badania naukowe z obecnością artefaktów z zakresu historii sztuki, archeologii i etnografii. Mógł on wejść do historii jako oświecony, promujący nauki monarcha, gdyby nie uległ jednocześnie romantycznej idei głębokiej więzi władcy i narodu, która powinna znaleźć wyraz i spełnienie we wspólnej wierze chrześcijańskiej. Katedra berlińska w postaci, w jakiej zaprojektował ją Schinkel, nie odzwierciedlała z perspektywy Fryderyka Wilhelma IV w satysfakcjonujący sposób owego związku narodu z religią, stąd podjął on pomysł Andreasa Schlütera wzniesienia nad zachodnim portalem zamku kopuły jako widocznego $z$ oddali znaku harmonii narodu i dworu we wspólnej religii. Jako antymodel okresu poprzedzającego Wiosnę Ludów (Vormärz), liberalnego, demokratycznego ruchu, do którego przyłączył się również Kugler, kopuła stała się jednak złowrogą przepowiednią. W roku 1848, czasie rewolucji europejskich, wewnętrzne napięcia doprowadziły także w Berlinie do wybuchu zamieszek, podczas których, prawdopodobnie w konsekwencji błędnie przekazanej wiadomości, doszło do rozstrzelania znacznej liczby demonstrantów. Wydarzenia te ukazane są na przedstawieniu anonimowego autorstwa. Na zamku widoczna jest kopuła w budowie, która dzięki zastosowaniu śmiałej konstrukcji żelaznej osiągnęła niespotykaną w ówczesnym czasie średnicę. Jednak w rezultacie historycznych wydarzeń stała się jedynie symbolem represyjnej polityki władcy. Fryderyk Wilhelm IV, który po masowym zastrzeleniu wielkiej liczby demonstrantów kazał usunąć wojsko $z$ miasta, wydając tym samym samego siebie, musiał zmarłym oddać honor.

Wraz ze stłumieniem rewolucji w roku 1848 reputacja zamku jako siedziby Hohenzollernów została zszargana. Od tego momentu - i na tym polega 
czwarty wymiar historyczny - na szereg dziesięcioleci utracił on dla Hohenzollernów swą reprezentacyjną funkcję. Nadal pełnił rolę siedziby urzędów i instytucji finansowych, lecz na więcej niż jedno pokolenie pozbawiony został swej funkcji pierwotnej.

\section{CESARSTWO I REWOLUCJA}

Dopiero wraz z powstaniem Drugiej Rzeszy w roku 1871 i objęciem tronu przez cesarza Wilhelma II zamek definitywnie przyjął funkcję, która z późniejszej perspektywy była mylnie przypisywana całej jego historii przy jednoczesnym pomijaniu jego dotychczasowego przeznaczenia. Jako centralna rezydencja dynastii Hohenzollernów stał się symbolem ich nieszczęsnych rządów.

Za złowrogą zapowiedź przyszłych wydarzeń uznaje się tzw. konferencję kongijską, która zdecydowała o podziale terytorialnym Afryki na europejskie strefy własności. Spotkanie to mogło odbyć się zarówno w Brukseli, Londynie czy Paryżu, a w Berlinie odbyło się nie w zamku, lecz w pałacu kanclerza Rzeszy przy Wilhelmstraße. Jednak ponieważ końcowy dokument został przypieczętowany w zamku, do dziś wydaje się, jakoby miał on swój udział w ówczesnych fatalnych decyzjach. Pod rządami cesarza Wilhelma II doszło do silnego spotęgowania patosu, które spowodowało, że zamek zaczęto postrzegać jako współodpowiedzialny za militaryzację i umocnienie imperialnych pretensji cesarstwa niemieckiego. Upadek cesarstwa nastąpił wraz ze szturmem na Zamek Berliński. Jeden z paradoksalnych zwrotów, do których wymyślenia niezdolna byłaby nawet wyobraźnia poety, sama historia natomiast tak, sprawił, że charakterystyczny fragment zamku stał się relikwią idei komunistycznej. Chodzi tu o portal IV, z którego zgodnie z przekazem przywódca komunistów Karl Liebknecht proklamował republikę socjalistyczną.

W Republice Weimarskiej zamek - w roku 1920 - stał się w całości własnością publiczną. Szczególne znaczenie miał fakt, że również w tym roku do pomieszczeń zamkowych wprowadził się uniwersytet, aby móc wreszcie zapewnić Instytutowi Psychologii wystarczająco duże pomieszczenia i umożliwić prowadzenie badań berlińskiej szkole psychologii postaci (Gestaltpsychologie). Aż do momentu emigracji światowej sławy psychologów gestaltyzmu - Wolfganga Köhlera, Maxa Wertheima i Rudolfa Arnheima - berlińska szkoła psychologii stworzyła w salach Zamku Berlińskiego podstawy swego przyszłego znaczenia, a po emigracji oddziaływała - szczególnie w Stanach Zjednoczonych - nie tylko w dziedzinie projektowania graficznego, lecz także we wczesnej informatyce, czego skutki odczuwalne są do dziś. 
Ponowne połączenie zamku i świata nauki w czasach Republiki Weimarskiej jest zatem piątym ogniwem, które z perspektywy historycznej wyznaczyć można w łańcuchu najważniejszych wydarzeń w historii zamku.

\section{ZNISZCZENIE ZAMKU JAKO PRZEGNANIE DEMONA}

Narodowi socjaliści w obliczu swego dążenia do stworzenia z gruntu nowej, własnej historii, pomimo całej historycznej pseudolegitymacji, jaką zamek oferował tego wieczoru roku 1933, kiedy Hitler przejął władzę w Niemczech, nie mieli dla niego określonej funkcji.

Centrum Berlina zostało niemal całkowicie zrównane z ziemią, sam zamek natomiast niemal cudownym trafem nie uległ tak silnym zniszczeniom, aby musiał być poddany rozbiórce. Wręcz przeciwnie, pojawiły się inicjatywy doprowadzenia do jego odbudowy. Jednak zarówno na zachodzie, jak i na wschodzie nastroje nie sprzyjały jakiejkolwiek formie restauracji. Ten w najróżniejszy sposób wyrażany wstręt do wszelkiego rodzaju rekonstrukcji nabrał wkrótce wymiaru historyczno-politycznego. W znaczącym manifeście architektów z roku 1947 proklamowano: „Zniszczone dziedzictwo nie może być rekonstruowane $\mathrm{w}$ formach historycznych, może być odtwarzane jedynie dla nowych funkcji i w nowych formach". Rekonstrukcjom zarzucano, że stanowią próbę usunięcia pamięci o spowodowanych przez Niemców zniszczeniach, które dotknęły ich samych.

Wschodnioberlińskim rozwiązaniem okazało się wysadzenie zamku w powietrze (il. 8). Przypomnieć jednak trzeba o głosach sprzeciwu wobec tego zamiaru. Mój poprzednik na Uniwersytecie Humboldtów z czasów powojennych, historyk sztuki Richard Hamann, w sierpniu 1950 roku przedstawił premierowi Niemieckiej Republiki Demokratycznej Otto Grotewohlowi kategoryczne memorandum w sprawie zachowania zamku:

Berlin jest ubogi w pomniki przeszłości. Posiada jednak dzieło wpisujące się w szereg najwspanialszych zabytków przeszłości, wymieniane oraz reprodukowane we wszystkich syntezach historii sztuki świata: Zamek Berliński. Jego twórcą był najwybitniejszy rzeźbiarz i architekt północnych Niemiec, Andreas Schlüter. Stoi w ruinie, wciąż jednak fascynując swym rozmachem i monumentalnością, jako reprezentant specyficznego północnoniemieckiego baroku, który godnie stanąć może u boku rzymskiej Bazyliki św. Piotra Michała Anioła czy Luwru w Paryżu.

Słowa te ukazują, jak głęboką identyfikację historyczną wzbudzała estetyka ruin zamku. Został on dotkliwie trafiony przez bomby, lecz jego stan nie po- 


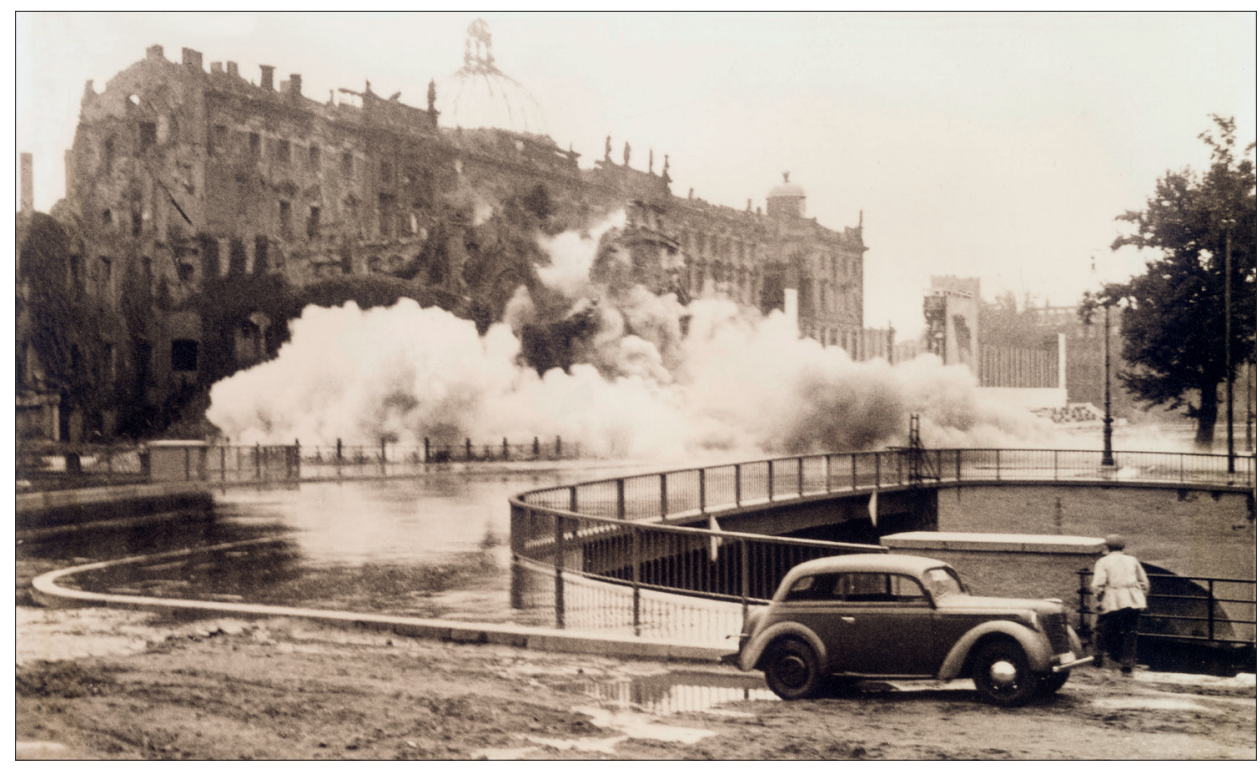

8. Wysadzenie zamku w powietrze, 1950

zostawiał wątpliwości, że można go uratować. Przerażenie wobec ewentualności, że budynek mógłby został rzeczywiście wysadzony w powietrze, wyraża się w stwierdzeniu: „Wszystkich historyków sztuki [...] sama myśl o możliwości zniszczenia zamku i tego historycznego centrum Berlina przyprawia o mdłości". Wszelkie apele pozostały jednak bezowocne.

Szóstym etapem w historii zamku był zatem jego dwojaki koniec: $z$ powodu zniszczeń wojennych podczas nalotów oraz celowej rozbiórki przez Niemiecką Republikę Demokratyczną, która uważała zamek za przeciwieństwo swego własnego powstania. Negatywna konotacja zamku z wydarzeniami roku 1848 oraz z jego funkcją w czasach Drugiej Rzeszy zadecydowała o ikonoklastycznym wyroku śmierci na niego.

\section{PAEAC REPUBLIKI}

Na miejscu zamku powstał rozległy plac, wykorzystywany do parad organizowanych 1 maja i przy innych okazjach. Jednak zaistniała w ten sposób pustka była tak trudna do zniesienia, że władze postanowiły na miejscu starego zamku wybudować pałac, który wzmocnił proces stopniowej modernizacji architektury NRD (il. 9). Jako „Pałac Republiki” budynek ten współtworzył historię architektury. W NRD był on popularny, ponieważ oferował rozrywkę 


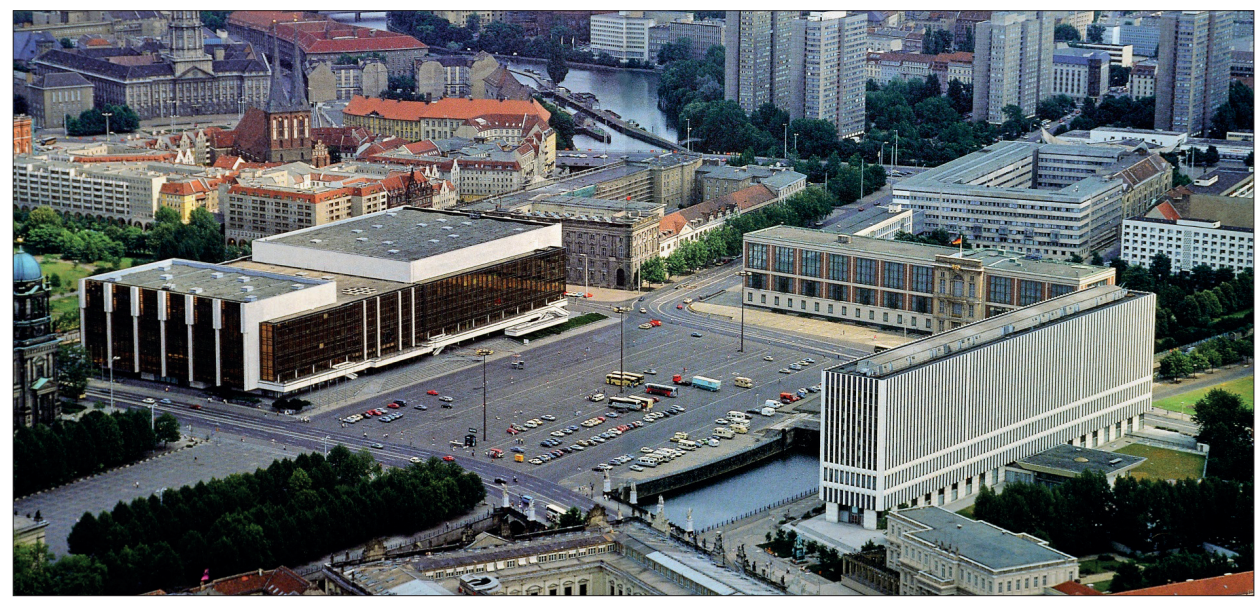

9. Panorama lotnicza Placu Zamkowego, lata 90.

i możliwość spotkań, które poza nim nie były w okolicy dostępne. I właśnie z tego powodu był znienawidzony przez krytyków reżimu.

Po zjednoczeniu Niemiec w roku 1990 Pałac Republiki stał się przedmiotem dyskusji w tym samym stopniu co stary Zamek Berliński po roku 1945. Kiedy podjęto decyzję o jego zburzeniu, jako powód podano, że zanieczyszczenie budynku azbestem jest tak wysokie, że dalsze użytkowanie go nie jest możliwe, a renowacja byłaby bardziej kosztowna niż rozbiórka. Tym uzasadnieniem, na którego podstawie należałoby zburzyć również szereg innych budynków w mieście, między innymi Centrum Kongresowe w Berlinie Zachodnim, starano się choćby retorycznie uniknąć wrażenia, jakoby decyzję podjęto ze względów politycznych. W rzeczywistości jednak na decyzję tę wyraźnie wpłynął wciąż niezapomniany wstrząs wywołany zburzeniem Zamku Berlińskiego; jego oddziaływanie przyczyniło się do usunięcia Pałacu Republiki, co dokonało się w długim, realizowanym niejako w akcie zemsty bolesnym procesie, któremu towarzyszyły wybitne przedsięwzięcia performatywne.

Budowa i wyburzenie głównego dzieła architektury NRD - jako znaki epoki republiki socjalistycznej i jej upadku - były siódmym ważnym wydarzeniem związanym z historią Zamku Berlińskiego i terenu pozamkowego. Pozostał jedynie portal IV, który w formie relikwii budowlanej komunizmu uratowano przed wyburzeniem zamku w roku 1950, aby wbudować go we wzniesiony w roku 1963 budynek Rady Państwa NRD (il. 10). Kompleks ten z pewnością należy do najbardziej surrealistycznych konstrukcji w historii architektury. 


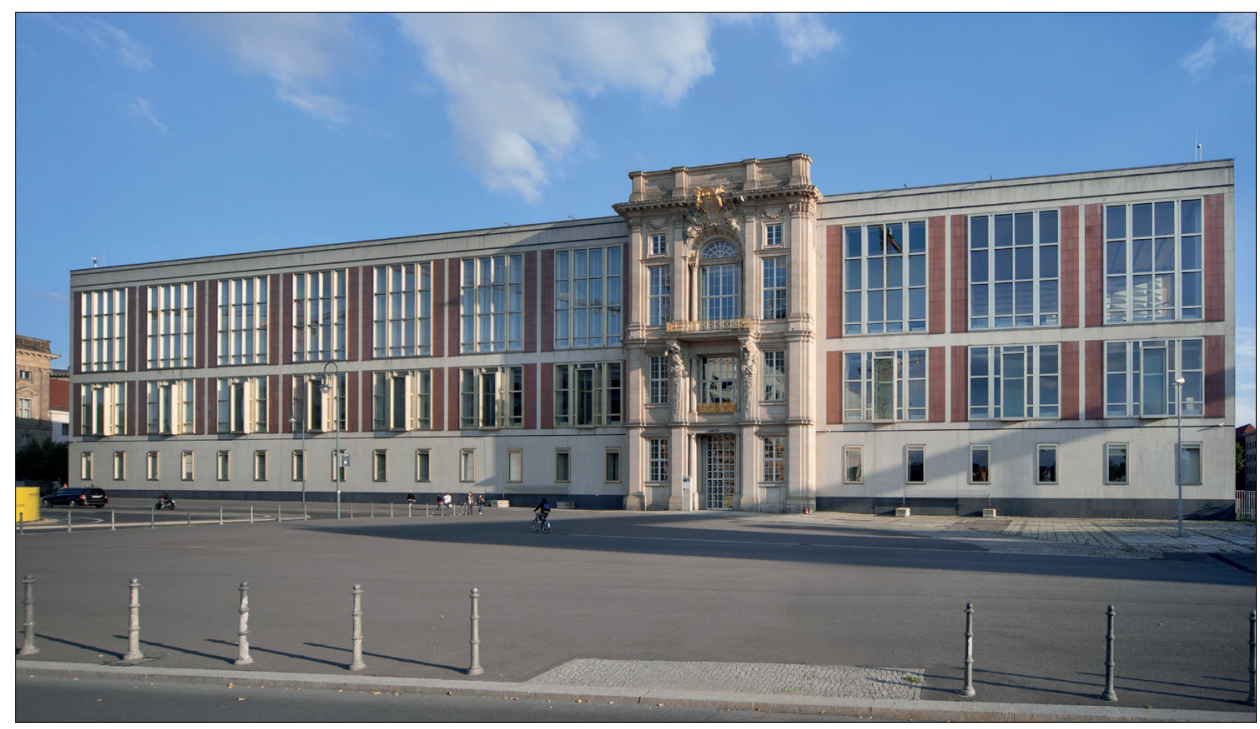

10. Budynek Rady Państwa NRD z portalem IV Zamku Berlińskiego

\section{DECYZJA O ODBUDOWIE}

Tymczasem rozgorzała dyskusja wokół rekonstrukcji zburzonego zamku. Ogłaszano konkursy owocujące niezwykle pomysłowymi projektami, lecz od chwili, gdy imponujące wrażenie wywarł model zamku w skali $1: 1$, wykonany w roku 1993 z inicjatywy hamburskiego zwolennika rekonstrukcji Wilhelma von Boddiena, nie było już alternatywy dla rekonstrukcji choćby szaty zewnętrznej. Sytuacja ta jednak w żadnym wypadku nie rozwiązywała jeszcze otwartej kwestii funkcji użytkowej wnętrz. W roku 2000 komisja ekspertów o nazwie „Historyczne Centrum Berlina” („Historische Mitte Ber$\operatorname{lin}^{\prime \prime}$ rozpoczęła prace nad tym, jaką treścią wypełnić wnętrza zrekonstruowanego zamku. Po powołaniu mnie na Uniwersytet Humboldtów w roku 1992 otrzymałem zadanie, aby zinwentaryzować i skatalogować zbiory Uniwersytetu $z$ zakresu historii nauki. Jednym $z$ wyników tych badań, które podjąłem wspólnie $z$ matematykiem Jochenem Brüningiem, była zorganizowana w roku 2000 w berlińskim Gropius Bau wystawa pod tytułem "Teatr przyrody i sztuki". Nawiązywała ona do pomysłu Leibniza połączenia założonej w roku 1700 w Berlinie Akademii Nauk z "Theatrum Naturae et Artis”. W ten sposób niespodziewanie licznym zwiedzającym wystawę udało się zaprezentować pierwotne zasoby zbiorów uniwersyteckich. W salach wystawowych odbyło się wiele warsztatów oraz dyskusji, dzięki czemu ekspozycja wniosła również swój wkład w nauczanie akademickie. 
Mając na uwadze wyniki badań i wystawę, przedstawiłem w roku 2001 komisji „Historyczne Centrum Berlina” koncepcję, aby zbiory uniwersytetu, stanowiące podstawę jego sukcesu, ponownie powiązać koncepcyjnie z zamkiem i przywrócić dawny związek zamku i uniwersytetu. Równocześnie Klaus Lehmann jako prezes i Peter Klaus Schuster - dyrektor muzeów Fundacji Pruskiego Dziedzictwa Kulturowego (Stiftung Preußischer Kulturbesitz) przedstawili pomysł zwrócenia pozaeuropejskich kolekcji do zamku, a tym samym zakreślenia funkcji rekonstruowanemu budynkowi. Komisja postanowiła przyjąć koncepcje Fundacji Pruskiego Dziedzictwa Kulturowego i Uniwersytetu oraz wyznaczyła oba organy jako podmioty użytkujące Forum Humboldtów. Jako trzeci podmiot dołączyło miasto Berlin, które zamierzało zainstalować w zamku Bibliotekę Miejską celem ożywienia tego miejsca, a wzorem było tu paryskie Centrum Pompidou. W roku 2002 koncepcja ta po bardzo budującej dyskusji została zatwierdzona przez niemiecki Bundestag. Skuteczny okazał się podstawowy zamysł wykorzystania zbiorów z dawnej zamkowej kunstkamery i umożliwienia ich oddziaływania w zmienionych współcześnie warunkach. Aplauz ze strony opinii publicznej był znaczny i po takim pozytywnym przyjęciu powinno było dojść do szybkiej realizacji projektu. Jednak kryzys gospodarczy, który dotknął kraj w pierwszych latach nowego stulecia, sprawił, że wobec liczby ponad 5 milionów bezrobotnych rekonstrukcja zamku Hohenzollernów, angażująca znaczne środki z budżetu publicznego, byłaby posunięciem dalece niestosownym. Projekt postanowiono zawiesić lub z niego zrezygnować. Jednak procesów, które w tej sprawie uruchomiły się już $\mathrm{w}$ ministerstwach, nie można było $z$ dnia na dzień zatrzymać, gdyż w międzyczasie podpisano już szereg kontraktów, które wymagały kontynuacji prac. Z tego względu projekt odbudowy zamku był kontynuowany poza świadomością publiczną, mimo że oficjalnie został zamrożony. Wyjaśnia to, dlaczego w grudniu 2007 roku zupełnie niespodzianie rozpisano konkurs na projekt zamku oraz powołano komisję decydującą o jego formie. Komisja miała bezwzględnie strzec podstawowej zasady, zgodnie z którą elewacje zewnętrzne budynku należało odtworzyć w niezmienionej szacie historycznej. Jako ósme ogniwo naszego łańcucha wydarzeń wyłania się zatem podjęta po raz pierwszy kwestia rekonstrukcji nieistniejącego zamku, rozpoczynając tym samym historię, która ma zostać sfinalizowana pod koniec roku 2019.

\section{ODBUDOWANY ZAMEK}

Konkurs wygrał projekt włoskiego architekta Franca Stelli. Ponownie o charakterze Zamku Berlińskiego zadecydowała włoska tradycja architektoniczna, która naznaczyła dzieło Andreasa Schlütera z około roku 1700, kie- 
dy to w bardzo subtelny sposób stworzył on plastyczną kompilację włoskich form szesnasto- i siedemnastowiecznych. Tym razem na szatę zamku wpłynęło nawiązanie do włoskiego racjonalizmu.

Twórczość Stelli wywodzi się z nurtu w historii architektury XX wieku, który wykształcił się pod nazwą włoskiego racjonalizmu po pierwszej wojnie światowej, aby przeciwstawić antyhistorycznemu zapałowi futurystów modernizm nawiązujący do zasad budownictwa antycznego, radykalnie redukujący jednak jego formy architektoniczne do ich matematycznego rdzenia. Kompozycja bazuje na zasadzie kontrastu pomiędzy gładkimi ścianami a silnie rozczłonowanymi partiami, jak to $\mathrm{w}$ wielu wariantach pokazał czołowy przedstawiciel nurtu Giuseppe Terragni. Sam Stella kilkakrotnie korzystał $z$ tego rozwiązania, między innymi w swym kompleksie szkolnym w Orgiano. Podstawowa zasada włoskiego modernizmu, konstruującego wszelkie formy według zasad matematycznego ratio, proporcji i jasności, zadecydowała o odrzuceniu przez Stellę możliwości przeplecenia kompozycji Schlütera nowo wykoncypowanymi przez niego partiami. Obie koncepcje ostro się zderzają, w tej konfrontacji jednak wyraźniej ze sobą współgrając, aniżeli pozwoliłoby na to pomieszanie obu stylów. Z surową wyrazistością zasada ta dochodzi do głosu w skrzydle wschodnim, które w kierunku Szprewy zainscenizowane jest jako potężny rygiel, zamknięcie samego siebie. Również i tam, gdzie nowy budynek styka się $z$ rekonstrukcją historycznych elewacji po stronie północnej i południowej, nie ma harmonijnego przejścia. Pojawiający się w tym miejscu uskok sprawia raczej wrażenie, że skrzydło wschodnie $z$ właściwym odstępem wznosi się przed właściwą budowlą. Kompozycja elewacji Stelli przewija się w całym budynku. Zaskakującym rozwiązaniem jest powtórzenie wariacji zewnętrznej elewacji skrzydła wschodniego po zachodniej stronie dziedzińca wewnętrznego, tzw. dziedzińca Schlütera (il. 11). W ten sposób rodzi się harmonia płynąca ze zróżnicowania. Kontrast pomiędzy gładko polerowanym kamieniem w elewacji Stelli a historyczną elewacją dziedzińcową Schlütera tworzy własną, różnorodnie się otwierającą kompozycję.

W czerwcu ubiegłego roku swoją inaugurację miała nowo wybudowana Brama Eosandera (il. 12). W ramach dwudniowej imprezy okolicznościowej zaprezentowano program, który przyciągnął prawie 40000 osób. To był naprawdę budujący moment, kiedy portal i zdobiące go rzeźby odegrały rolę głównych protagonistów w minimalistycznym otoczeniu. Alegorie Famy umieszczone w przyłuczach stanowią wspaniałe repliki, które w kunsztowny sposób udało się wkomponować jako spolia w zachowany oryginalny fragment. Rekonstrukcja ta niejako sama dekonstruuje temat tej nowej odsłony antycznego łuku tryumfalnego, gdyż przedstawione zwycięstwo samo w sobie jest fragmentem gruzu. Zrekonstruowana brama wpisana jest niczym rekwizyt, dekoracja te- 


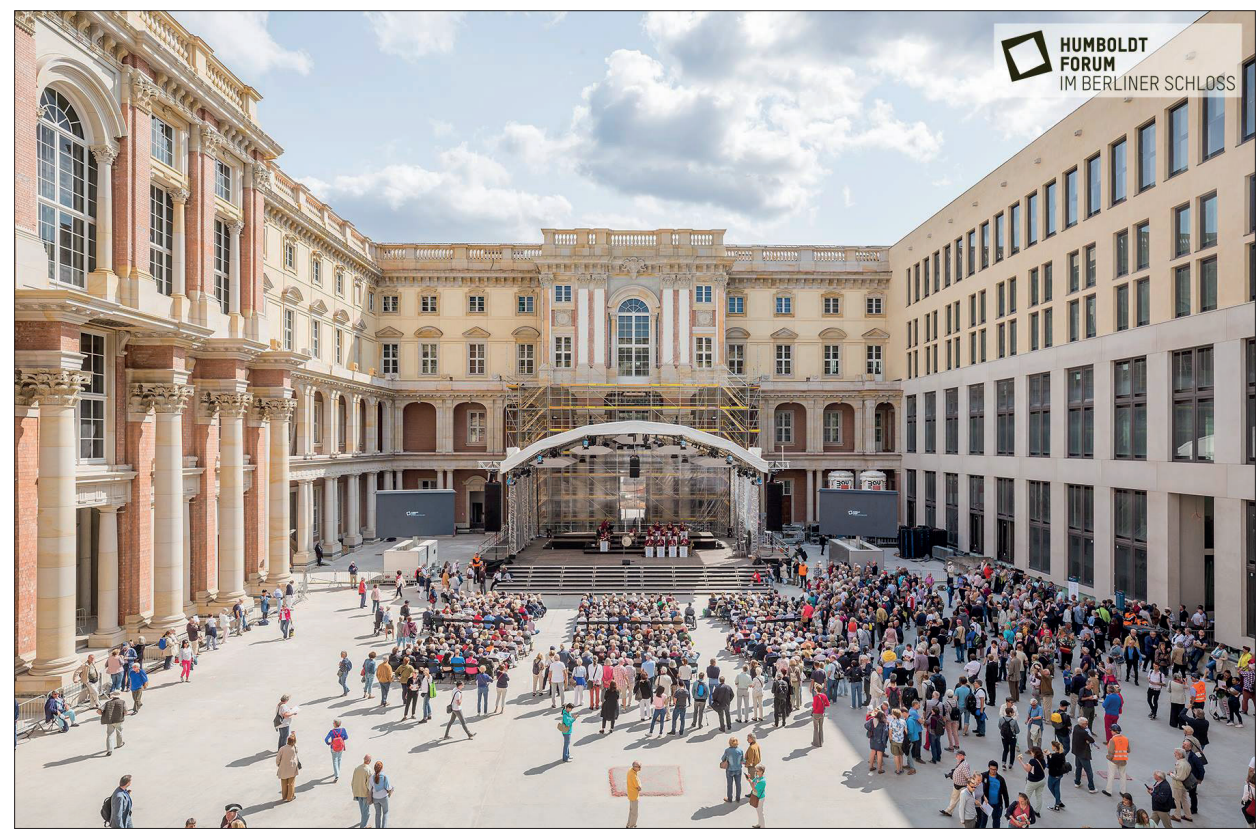

11. David von Becker, Dziedziniec Schlütera, Zamek Berliński, 2018

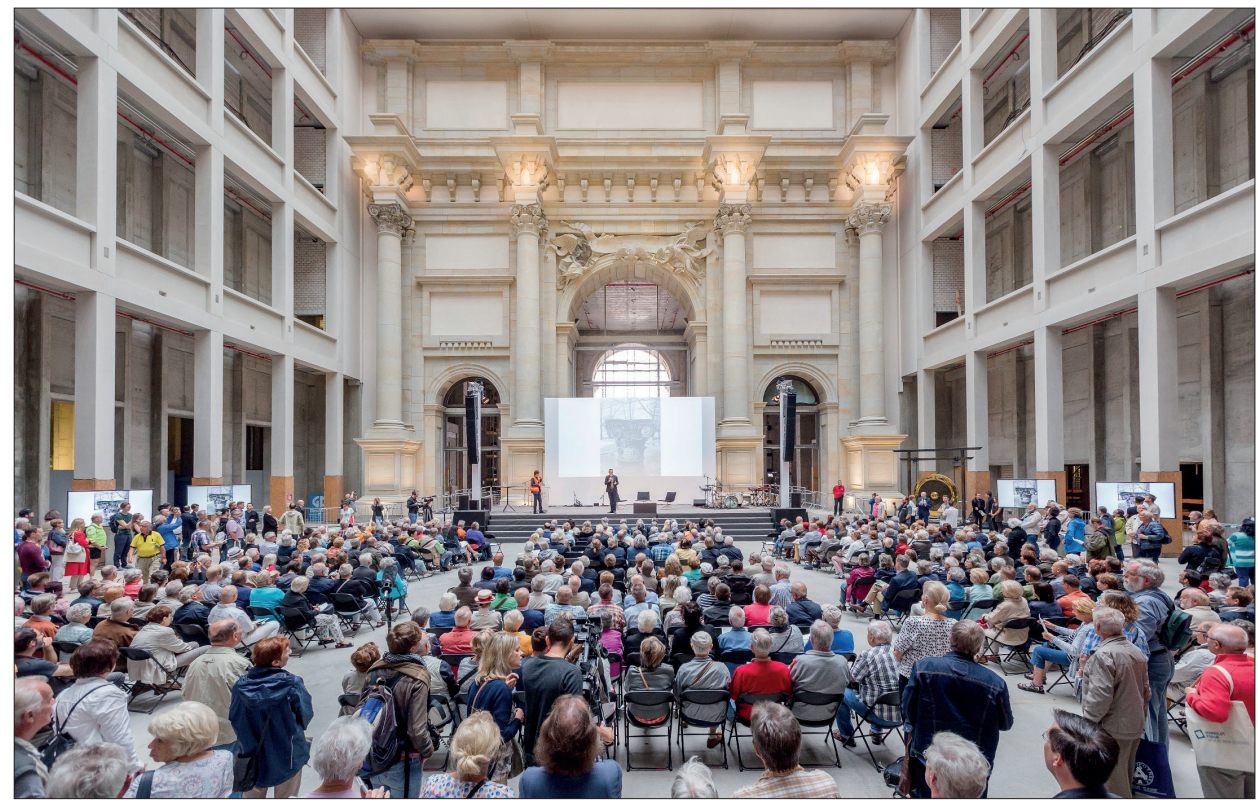

12. Atrium z rekonstrukcją portalu Eosandera, Zamek Berliński, 2018 
atralna, w większy nowoczesny kontekst. Oba bieguny działają na siebie i przeciwko sobie. Ogromny hol wejściowy charakteryzuje surrealistyczne napięcie między rzymską monumentalnością a włoskim modernizmem. Z jednej z galerii roztacza się widok na bramę Eosandera i atrium. Wzrok pada na oryginalne kapitele, które $z$ kolei rekonstrukcyjnie przywołują starożytny Łuk Septymiusza Sewera z Rzymu do Berlina. Natomiast powyżej i poniżej znajdują się dzisiejsze rekonstrukcje. Zarówno historycznie, jak i współcześnie Zamek Berliński odzwierciedla pewnego rodzaju włoskość (italianità), zasadniczo zaprzeczającą wszelkim wyobrażeniom o inkorporowaniu tu restauracyjnych lub zgoła militarystycznych treści. Komisję przekonała w znacznej mierze także umiejętność Stelli nadania budowli urbanistycznej jakości poprzez prowadzące przez rozległy areał zamkowy ulice, otwarte zarówno w dzień, jak i w nocy.

Dziewiątym elementem historycznych wydarzeń jest zatem powrót owej italianità architektury zamkowej, zainicjowanej przez Andreasa Schlütera. Tym razem to włoski modernizm determinuje charakter elewacji wschodniej i dziedzińców Forum Humboldtów.

\section{HISTORIA I TERAŹNIEJSZOŚĆ}

Im wyraźniej zarysowywały się kształty rekonstrukcji, tym silniejsze stawały się słowa krytyki, która od samego początku przeciwna była rekonstrukcji, uważając, że będzie ona stanowiła nową odsłonę ducha Hohenzollernów, a tym samym głęboko reakcyjnego sposobu myślenia, dając mu nowy bodziec. Dyskusje, które od czasu ustawienia fikcyjnej elewacji zamku w roku 1993 wydawały się zakończone, powróciły i powracają z niespodziewaną gwałtownością, a z pewnością towarzyszyć będą budowli również po jej ukończeniu. Powodem tego jest fakt, że Federalnej Republice Niemiec pomimo zjednoczenia kraju dotąd nie udało się stworzyć pozytywnie naznaczonej alternatywy w postrzeganiu niemieckiej historii. Problem polega na tym, że w Niemczech wszystko, co obiera jakikolwiek pozytywnie ukierunkowany cel, mimowolnie łączone jest z podejrzeniem o chęć ograniczenia wspomnień o koszmarze okresu po roku 1933. Raison d'Etre Republiki Federalnej Niemiec od początku jej ustanowienia polegała w dużej mierze na tym, aby już nigdy nie dopuścić do niczego, co mogłoby się równać z nazizmem. Jej legitymacja do dziś bazuje na negacji reżimu nazistowskiego. Warunkiem istnienia niemieckiej państwowości jest refleksja nad jej naznaczoną winą historią. Na tym tle w roku 2000 zrodził się pomysł, aby w centrum stolicy kraju, który w roku 1939 pogrążył wielkie obszary świata w otchłani, stworzyć przestrzeń, w której zestawiono by artefakty z najróżniejszych światowych kultur, aby wspól- 
nie ze zbiorami bliskowschodnimi i europejskimi Wyspy Muzeów stworzyły wyjątkowy kompleks muzealny. Zgodnie ze słowami wielkiego antropologa Claude'a Lévi Straussa miałby on na celu pokazanie, co ostatecznie łączy ludzi, a nie prowadzi do zniszczeń i dewastacji. Odwrócenie tego stanowiska w roszczeniową postawę porządkowania świata przez pryzmat europejskich, w tym szczególnie niemieckich, kategorii, napiętnowanych per se winą, wprowadza $z$ mojego punktu widzenia zamęt, gdyż podejście takie umacnia to, co właściwie zwalcza. Na tle tego, co próbowałem naszkicować Państwu w dziesięciu krokach, być może bardziej zrozumiałe staje się, dlaczego nadal uważam za obowiązek, aby nawiązać do tradycji ustanowionej przez Leibniza, Georga Forstera i braci Humboldtów.

Zamek Berliński od czasu jego budowy w roku $1700 \mathrm{w}$ coraz to nowych uwarunkowaniach odzwierciedla w paradygmatyczny sposób fale dyskusji toczonej na temat takiej właśnie orientacji. Zbudowany z myślą o italianizacji pruskiego centrum, nie stanowiąc w żadnej mierze ucieleśnienia władzy, lecz naczynie społecznych więzi, był raczej Lewiatanem aniżeli koroną, miejscem mikrokosmicznego skurczenia świata w kunstkamerze w niehierarchiczny sposób. Będąc matką berlińskiej Alma Mater, miejscem rewolucji roku 1848 oraz upokorzenia króla pruskiego, stał się następnie ośrodkiem propagandy roszczeń wielkomocarstwowych Hohenzollernów w Drugiej Rzeszy, a później miejscem republikańskiego zawłaszczenia przez Republikę Weimarską. Zniszczony wreszcie jako symbol pruskiego militaryzmu i następnie odbudowany w postaci kompromisu autentycznych elewacji zewnętrznych $z$ nowoczesnym życiem wewnętrznym, aby przyiąć tradycyjnych użytkowników - Uniwersytet i pozaeuropejskie zbiory, a także miasto Berlin, stał się ostatecznie przedmiotem zaciekłych sporów jako medium uniwersalnej orientacji bądź jako reakcyjne odtworzenie zarzuconego historyzmu. W obliczu tych licznych zwrotów w swej historii Zamek Berliński może być postrzegany jako swego rodzaju psychogram różnorodnych stadiów niemieckiego stanu ducha.

Wszystko to jest tak paradoksalne jak samo życie, jeśli pozwolą Państwo na tak trywialne stwierdzenie. Lecz nie dochodzę do żadnego innego wniosku. Losy Zamku Berlińskiego rozgrywały się pomiędzy zniszczeniami a nadzieją na harmonijne współżycie społeczne, którego horyzonty wyobrażano sobie znacznie szerszej, aniżeli mogły pozwolić na to lokalne warunki, i w ten sposób los jego potoczy się dalej. W swej szacie zewnętrznej, będącej jednym $z$ najbardziej imponujących tworów europejskiego baroku, pozostanie ze względu na swą historię miejscem projekcji różnorakich stanowisk. Jeżeli miałoby się to powieść - jednakże już bez udziału historii o podobnie dramatycznych wstrząsach, jakie ucieleśnia nowo wybudowany zamek - wówczas Forum Humboldtów spełniłoby swoje zadanie. 


\section{ZAKOŃCZENIE}

W ten sposób dotarłem do końca mojego wystąpienia. Powód, dla którego stanąłem przed Państwem nie bez emocjonalnego zaangażowania - poza wypowiedzianymi słowami - tłumaczą dwie fotografie (il. 13). Pierwsza z nich pochodzi ze spuścizny mojego ojca. Została wykonana w czasach założenia poznańskiej historii sztuki. Ukazuje mojego ojca na koniku na biegunach, który jako element sztafażu znajdował się w zakładzie fotograficznym. Na rewersie fotografii widoczna jest nazwa owego zakładu. Rodzice mojego ojca mieszkali w Poznaniu, stąd zdjęcie to wykonano w Atelier Apollo przy Wilhelmstraße, dzisiejszych Alejach Marcinkowskiego, a skoro zebraliśmy się dzisiaj w Zamku Cesarskim Wilhelmsschloss, w Centrum Kultury, to istnieje tu pewne luźne powiązanie. Adam Labuda, z którym spędziłem szczęśliwe wspólne lata pracy na Uniwersytecie Humboldtów w Berlinie, jest prawie w tym samym wieku co ja. Gdyby nie horror inwazji na Polskę ze wszystkimi jej konsekwencjami, Adam Labuda i ja być może uczęszczalibyśmy do tej samej klasy w jednym z poznańskich liceów i zaprzyjaźnilibyśmy się ze sobą
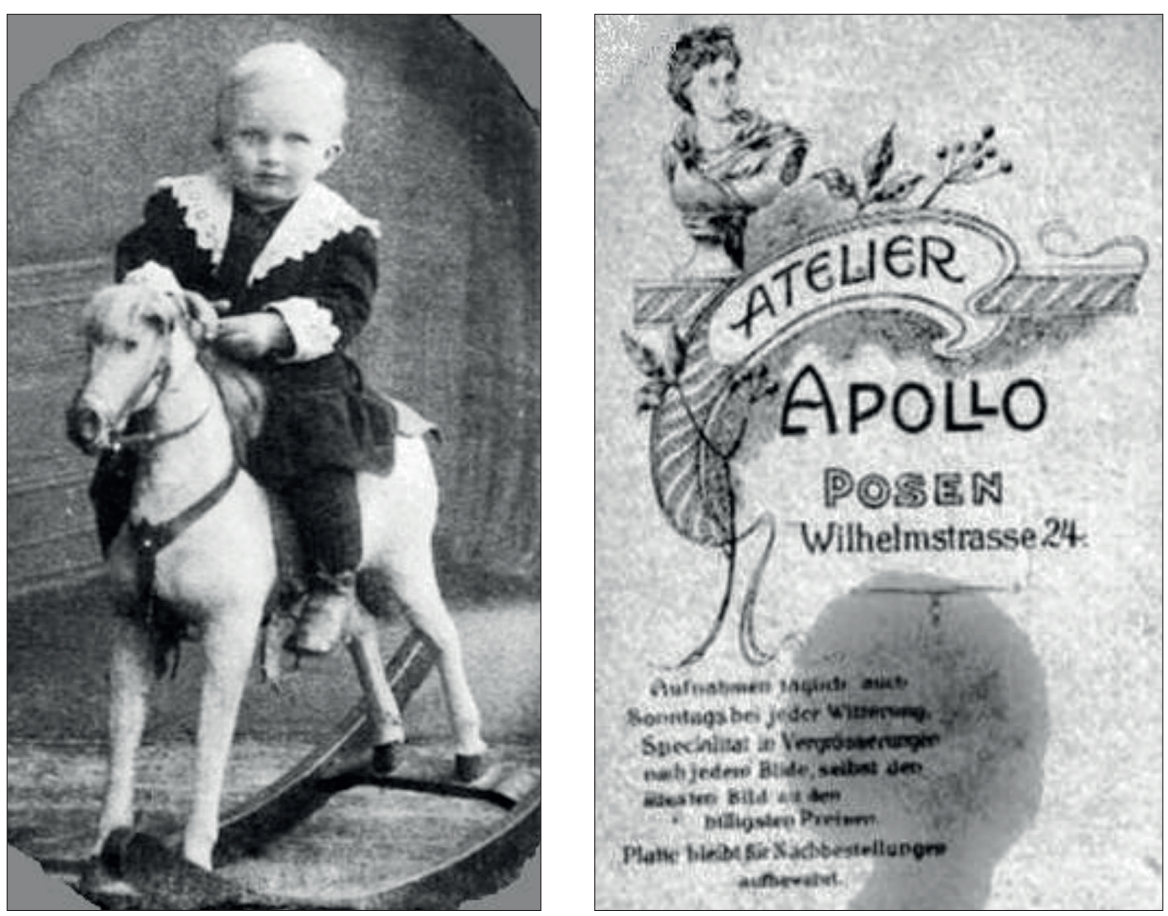

13. Gerhard Bredekamp, fotografia, Atelier Apollo, Poznań, ok. 1919 
znacznie wcześniej, niż stało się to w końcu jeszcze przed upadkiem muru berlińskiego.

Szanowni Państwo, mam nadzieję, że udało mi się wyjaśnić, dlaczego możliwość wypowiedzi przed Państwem tu w Poznaniu na temat dramatu historycznego związanego z Zamkiem Berlińskim, pierwszego wielkiego zlecenia polskiego dworskiego artysty Schlütera, była dla mnie szczególnie ważna. Ufam, że udało mi się wykazać, że w swej szacie architektonicznej, reprezentującej złamane wielkomocarstwowe ambicje, oraz w obliczu idei swej kunstkamery wart jest on obrony i wypełnienia nową treścią.

Drodzy Państwo, poznańskiemu Instytutowi na kolejne 100 lat życzę pełnej sukcesu kontynuacji wspaniałego pierwszego wieku działalności! Bardzo dziękuję za uwagę.

Tłumaczenie z jęz. niemieckiego: Agnieszka Lindenhayn-Fiedorowicz

\section{BIBLIOGRAFIA}

Andreas Schlüter und das barocke Berlin. Ausstellungskatalog, red. H.-U. Kessler, Berlin und München 2014

Bernau N., Von der Kunstkammer zum Musenarchipel. Die Berliner Museumslandschaft 1830-1994, w: Museumsinszenierungen. Zur Geschichte der Institution des Kunstmuseums. Die Berliner Museumslandschaft 1830-1990, red. A. Joachimidis, S. Kuhrau, V. Vahrson, N. Bernau, Dresden und Basel 1995, s. 15-35

Boddien W. von, Fassade. Der Palast der Republik hat sich überlebt, w: Volkspalast. Zwischen Aktivismus und Kunst, red. A. Deufhardt, S. Krempel-Klieeisen, M. Linienthal, H. Müller, Ph. Oswalt, Recherchen 30, 26.08.2008, S. 249-252

Bolz P., From Ethnographic Curiosities to the Royal Museum of Ethnology. Early Ethnological Collections in Berlin, w: Adolf Bastian and his Universal Archive of Humanity. The Origins of German Anthropology, red. M. Fischer, P. Bolz, und S. Kamel), Hildesheim, Zürich, New York 2007, s. 173-190

Bredekamp H., Der lange Atem der Kunstkammer: Das Neue Museum als Avantgarde der Vorvergangenheit, w: Museale Spezialisierung und Nationalisierung ab 1830. Das Neue Museum in Berlin im internationalen Kontext, red. E. Bergvelt, D. Meijers, L. Tibbe, E. van Wezel, Berlin 2011, „Berliner Schriftenreihe zur Museumsforschung", 29, s. 25-36

Bredekamp H., Das Schloss und die Universität: eine nicht endende Beziehung, w: Das Humboldt Forum. Die Wiedergewinnung der Idee, red. H. Bredekamp, P.-K. Schuster, Berlin 2016, s. 104-133

Bredekamp H., Berlin am Mittelmeer. Kleine Architekturgeschichte der Sehnsucht nach dem Süden, Berlin 2018 
Bredekamp H., Aby Warburg, der Indianer. Berliner Erkundungen einer liberalen Ethnologie, Berlin 2019

Bredekamp H., E. Dolezel, Die Berliner Kunstkammer und die Utopie von Tangermünde, w: Cranach und die Kunst der Renaissance unter den Hohenzollern. Kirche, Hof und Stadtkultur. Ausstellungskatalog, Berlin 2009, s. 137-141

Bredekamp H., M. Eissenhauer, Keimzelle Kunstkammer, w: Das Humboldt-Forum im Berliner Schloss. Planungen. Prozesse. Perspektiven, München 2013, s. 50-57

Buddensieg T., Berliner Labyrinth. Preußische Raster, Berlin 1993

Dieckmann F., Von Schlüter zu Stella oder: Die Fehler des Politbüros, w: Das Humboldt Forum. Die Wiedergewinnung der Idee, red. H. Bredekamp, P.-K. Schuster, Berlin 2016, s. 20-36

Dolezel E., "Lehrreiche Unterhaltung“ oder "Wissenschaftliche Hülfsmittel“? Die Berliner Kunstkammer um 1800. Eine Sammlung am Schnittpunkt zweier musealer Konzepte, "JJahrbuch der Berliner Museen“ 2004, N.F., 46, s. 147-160

Dolelzel E., Der Traum vom Museum. Die Berliner Kunstkammer unter Jean Henry (1794-1805) und das Akademiemuseum des 18. Jahrhunderts, Berlin 2019

Franz Theodor Kugler. Deutscher Kunsthistoriker und Berliner Dichter, red. M. Espagne, B. Savoy, C. Trautmann-Walter, Berlin 2010

Geyer A., Geschichte des Schlosses zu Berlin, t. 1: Die kurfürstliche Zeit bis zum Jahre 1698, Textband und Bildband, Berlin 1993

Goldenbaum L., Ein Schloss in Erwartung kollektiver Sinnstiftung, w: Das Humboldt Forum. Die Wiedergewinnung der Idee, red. H. Bredekamp, P.-K. Schuster, Berlin 2016, s. 148-189

Hinterkeuser G., Das Berliner Schloss. Der Umbau durch Andreas Schlüter, Berlin 2003

Hinterkeuser G., Das Berliner Schloss. Die erhaltene Innenausstattung. Gemälde, Skulpturen, dekorative Kunst, Regensburg 2012, s. 100-107

Holland A., Johann Friedrich Eosander genannt von Göthe (1669-1728). Anmerkungen zu Karriere und Werk des Architekten, Ingenieurs und Hofmannes am Hof Friedrichs I. in Preußen, Weimar 2002

Humboldt Forum. Der lange Weg 1999-2012, red. V. König, A. Scholz, Berlin 2011, Reihe: Baessler-Archiv. Beiträge zur Völkerkunde, cz. 59

Das Humboldt Forum. Die Wiedergewinnung der Idee, red. H. Bredekamp, P.-K. Schuster, Berlin 2016

Kugler FTh., Handbuch der Kunstgeschichte, cz. 1-2, Stuttgart 1842

Peschken G., H.-W. Klünner, Das Berliner Schloß, Frankfurt am Main, Wien, Berlin 1982

Pratschke M., Gestaltexperimente unterm Bilderhimmel. Das Psychologische Institut im Berliner Stadtschloss und die Avantgarde, Basel 2016

Stella F, Ausgewählte Schriften und Entwürfe (= Franco Stella, cz. 1), Berlin 2010

Stephan P., Das Humboldt-Forum als moderner Weiterbau des Berliner Schlosses (= Franco Stella, cz. 2), Berlin 2010

Theater der Natur und Kunst. Theatrum Naturae et Artis. Wunderkammern des Wissens, Katalogband und Essayband, red. H. Bredekamp, J. Brüning, C. Weber, Berlin 2000 
Theuerkauff Ch., Zur Geschichte der Brandenburgisch-Preußischen Kunstkammer bis gegen 1800, w: Die Brandenburgisch-Preußische Kunstkammer, Ausstellungskatalog, Berlin 1981, s. 13-34

Vermeulen H.F., Before Boas. The Genesis of Ethnography and Ethnology in the German Enlightenment, Lincoln und London 2015

Wezel E. van, Die Konzeptionen des Alten und Neuen Museums zu Berlin und das sich wandelnde historische Bewußtsein, "Jahrbuch der Berliner Museen“ 2001, 43, Beiheft, Berlin 2003, s. 114-117

Horst Bredekamp

Humboldt-Universität, Berlin

FROM THE BERLIN PALACE TO HUMBOLDT FORUM. A PARADIGM OF CONFLICT IN GERMAN HISTORY

\section{Summary}

The lecture concerns the Berlin Palace (Stadtschloss) and presents a view of its long history, starting with its construction in the Baroque style by an artist of the Polish origin, Andreas Schlüter, up to its contemporary reconstruction with a new institutional function (Humboldt Forum). The ten sections of the text not only present architectural and artistic history of this residence but also pivotal historical events and contexts which affected the dimensions and meaning of its functioning. The palace, entangled into German history but also reflecting it, especially as regards the $19^{\text {th }}$ and $20^{\text {th }}$ centuries, becomes both a starting point for an evaluation of this history and posing questions about the future. Along with the ferociously debated, present-day reconstruction and its museum function, it also seems to be a psychogram of diverse stages of the condition of German spirit.

Keywords:

Berlin, Humboldt Forum, residential architecture, architecture and power, kunstkammer, university 